\title{
Features of Nursing Management Information Systems: A Systematic Review
}

\author{
Akram Fathian ${ }^{1}$, Hassan Emami ${ }^{2}$, Hamid Moghaddasi ${ }^{1}{ }^{*}$, Alireza Kazemi $^{1}$ and Reza Rabiei ${ }^{1}$ \\ ${ }^{1}$ PhD candidate, Department of Health Information Management and Technology, School of Paramedical Sciences, Shahid \\ Beheshti University of Medical Sciences, Iran
}

${ }^{2}$ Assistant Professor, Department of Health Information Management and Technology, School of Paramedical Sciences, Shahid Beheshti University of Medical Sciences, Iran

*Corresponding author: Hamid Moghaddasi, Associate Professor of Health Information Management \& Medical Informatics, Department of Health Information Management and Technology, School of Paramedical Sciences, P.O. Box 19395, Tehran, Shahid Beheshti University of Medical Sciences, Iran

\section{ARTICLE INFO}

Received: 慧 August 28, 2019

Published: 幽 September 11, 2019

Citation: Akram F, Hassan E, Hamid M, Alireza K, Reza Rabiei. Features of Nursing Management Information Systems: A Systematic Review. Biomed J Sci \& Tech Res 21(2)-2019. BJSTR. MS.ID.003582.

Keywords: Nursing Management, Information System, Decision Support System, Management Information System.

\section{ABSTRACT}

Background: A nursing management information system is a decision support system for nursing managers. The present literature review aimed to systematically examine the features of different nursing management information systems employed by nursing managers in different countries.

Method: For this purpose, PubMed, Scopus, and Web of Science databases were searched using various combinations of English words, including "management information system", "decision support system", "information system" and different equivalents of "nursing management". Research articles in English published between 2000 and 2018 were searched.

Results: Eventually, 21 articles were selected and analyzed. The analysis showed that different systems were used to meet various nursing management objectives. More often than not, the purpose of using nursing management information systems was to plan and manage human resources, measure nursing workload, determine the correct nurse-topatient ratios, run shifts, and manage and control costs. Furthermore, systems referred to as nursing management information systems were based on patient classification or workload measurement systems, or systems supporting planning and budgeting through integrating nursing resource information with hospital resource measurement. There was no centralized or consistent database for obtaining information required for nursing management objectives.

Conclusion: Countries employed various systems to provide diverse nursing management objectives, and the overriding goal of these systems was to plan and manage human resources.

\section{Introduction}

Healthcare organizations are widespread and complex organizations dealing with patients and care providers. To meet the expectations of patients and ensure their satisfaction, quality improvement has become a challenge for health care organizations [1-3]. The Institute of Medicine (IOM) has described the quality of healthcare as "the degree to which health services for individuals and populations increase the likelihood of desired health outcomes and are consistent with current professional knowledge" [4]. The quality of care is dependent on medical science and technology [5]. In health care organizations, clinical units are microsystems which are front, small, and operational units providing care to patients $[6,7]$.
Nursing departments are one such microsystem, typically managed by unit managers who are registered nurses. Professional nurses and other affiliated staff are directed, influenced, and managed by nursing managers in order to develop an elite, innovative, and revolutionized clinical culture $[8,9]$. Nursing managers must pay attention to the organization's ideas and priorities so as to accomplish the objectives of the organization [10].

In nursing, the purpose of care management is to coordinate the managerial and clinical dimensions of the nursing work process. The goal of the management dimension in nursing management is to coordinate the facilities and human resources in order to 
ameliorate the quality of patient care and enhance the performance of the nursing team, whereas the goal of the clinical dimension in nursing management is to meet healthcare needs [11]. Nowadays, nursing managers play different roles. Regardless of the place of service, role, or title, the main tasks of nursing managers are the same [12] and include the provision of care, maintenance of a healthy work environment, management of resources, and improvement of safety, quality, and health outcomes. To fulfill their roles and perform all the related tasks, nursing managers should analyze situations and make appropriate decisions [12-15]. They require extensive information to make a proper and effective decision $[16,17]$. Over recent years, the scope of nursing management has expanded, and its required information has dramatically increased in terms of quantity and variety $[12,16,18]$. It is clear that nursing managers require an integrated information system to manage their information [19]. Information systems support decision-making in a variety of ways, e.g. via data access and data management tools, reporting, documentation, communication, and statistical analysis [20].

Nursing managers utilize two groups of information systems in order to perform their tasks: first, public information systems used by various professional groups, and second, information systems specifically designed for nursing managers. These are information systems designed for nursing managers to support them in their decisions and planning for service delivery through improved access to information. In each unit, it manages the clinical and administrative affairs of nursing units, including resource, ward, and quality management; position control; recruitment; staffing; scheduling; planning; workload measurement; patientclassification; productivity management; clinical affairs management; evaluation; reporting; and automation [21-24]. To accomplish these tasks, the nursing management information system should be integrated with other hospital information systems to extract the required data. By receiving data from various sources and performing different types of processes and classifications, this system provides various reports for various references $[23,25]$.

Some tasks performed by nursing management information systems are as follows:

\section{Resource Management}

Such management encompasses human, financial, and physical resources [22].

Human Resources: Managing patient care in departments is not a simple task. Careful management of human resources is required on the part of nursing managers. To do this, they need to have access to accurate and timely information about all the features related to the allocation and utilization of human resources [22].

Financial Resources: Currently, in healthcare organizations, potential concerns as to economic issues appear to be more serious than before [22].
Physical Resources: Nursing managers are further obligated to supervise and maintain the physical facilities of their nursing units [22].

\section{Workload Measurement and Unit Staffing}

In nursing units, there has to be a balance between patient needs and the number of nursing staff. Working with a workload management method is the key to ensuring that such balance exists [24]. Nursing workload management systems assist nursing managers in staffing, budgeting, planning, and quality assurance by providing the required information [26].

\section{Patient Classification Systems (PCSs)}

PCSs provide exact clinical data for forecasting and allocating human resources. A PCS supplies the information needed for human resource management, accounting, budgeting, and other management tasks. It also assesses and classifies patients based on the acuity of their disease, need for care, and nursing activities that are necessary to meet their care needs during a specific period [27].

\section{Office Automation}

This is an electronic technology integrated with and utilized for administrating the office and supporting managers at all levels of organization [22].

\section{Evaluation}

The nursing management information systems use certain criteria to provide care and monitoring. The care criterion is the use of a human resource planning method that evaluates the length of time and nursing skills required to meet the needs of various patient groups. Monitoring is also conducted through evaluating the quality of care, the amount of time, skills, and other nursing activities performed to meet the needs of patients. Finally, based on the acquired data and nursing judgments, the most appropriate amount of time, skills, and patterns of activities are determined so as to meet the requirements of patients in different units [28].

\section{Reporting}

Nursing management information systems support managers with a wide range of reports, including financial reports on different aspects of budget information such as periodically produced budget summaries and the upcoming year's budget forecast. Other reports are those which help nursing managers make decisions for allocating different resources. The areas of higher priority in resources allocation are set based on these reports. Another group of these reports provides information on the employed human resources and include absenteeism indicators and indicators of the skill, knowledge, and experiences of the staff [22].

It is obvious that nursing management information systems support the decisions of nursing managers, not only from a managerial, but also from a clinical point of view; this system further combines clinical and management information which can improve nursing care and reduce costs [21-23]. 
The implementation of nursing management information systems requires that nursing managers learn more about the features of these systems to fully benefit from their implementation. In many cases, without involving the nursing managers, system analysts design systems that do not appear to be relevant, accurate, or useful enough to meet the requirements. Health information systems must be designed considering users' needs and requirements to support them in their daily routines effectively. Otherwise, the systems could make difficulties and negatively impact users' practice [29]. One way to overcome this challenge is to familiarize nursing managers with the features of nursing management information systems. Therefore, this review aimed to investigate the features of these systems.

\section{Materials and Methods}

\section{Study Identification and Selection}

Initially, the following research questions were posed to shape the subject matter of this systematic review:

What are the services of nursing management information systems?

What are Data Sources of nursing management information systems?

What are the Components of nursing management information systems?

Secondly, relevant studies were identified. The search strategy adhered to the Preferred Reporting Items for Systematic Reviews and Meta-Analyses (PRISMA) statement outlining methods for a systematic review [30,31].

The summary of each step is given below:

Data Sources and Search Strategy: PubMed, Scopus, and Web of Science databases were searched using various combinations of English words, including "management information system", "decision support system", "information system" and different equivalents of "nursing management". The MeSH databases were used to find equivalent terms. Additional articles were found through a bibliographic review in which a preliminary assessment of article title and/or abstract indicated potential eligibility for inclusion in the review.

Inclusion Criteria: Articles written in English and published from 2000 to 2018 studying the implemented nursing management information systems, reporting their features, and indexed in one of the mentioned databases were included in the present review.

Exclusion Criteria: In this review, articles employing the nursing management information system as a tool for purposes other than supporting nursing management, as well as articles not on the features of nursing management information system were excluded. Review papers, editorials, commentary articles, letters, and opinion articles were also eliminated.

Study Selection: After the removal of duplicates, the study selection screening process began with a title and abstract review and then proceeded to a full-text record review. All the authors independently reviewed the titles and abstracts of the articles to decide on acceptable ones. Disagreements on articles meeting the criteria were resolved by discussion. First, the title and the abstract were screened to identify studies that met the inclusion criteria. Next, full-text articles were retrieved and reviewed, and studies were selected based on inclusion and exclusion criteria as described above. Two full-text articles could not be retrieved and were consequently excluded. An annotated bibliography was created to organize the findings.

Data Abstraction: Data from each article were abstracted to an Excel worksheet. Columns were labeled with the following types of data: countries, systems, services, components, and data sources. Information was collected from the studies and placed within these columns for ease of comparison.

Data Analysis: The extracted data, including different nursing management information systems used in different countries, their services, data sources, and components were organized in a Table 1. To synthesize the features of nursing management information systems across the reviewed studies, the authors carefully read and compared the features extracted from each study and divided them into meaning units. The authors integrated or separately organized the features into keywords and phrases capturing the core content of each unit. The synthesized results were eventually organized in a Table.

Findings: The total number of articles found was 2107, of which 1181 were duplicates. After eliminating them, of the 926 remaining articles, 800 articles were removed based on a title revision. Then, 126 articles were reviewed based on the abstracts. In this stage, 85 articles were omitted based on their abstracts. The full text of the remaining 41 articles was examined, and 16 articles were selected. In addition, the references of the retrieved articles were reviewed, resulting in the selection of five papers. Finally, 21 papers remained for the final review (Figure 1). In this review, in order to study the features of each nursing management information system implemented in different countries, their services, components, and data sources from which the necessary data were extracted are discussed. Table 1 presents the characteristics of different systems used in different countries. Countries include Finland, Japan, China, Norway, the United States of America, Nordic countries, Italy, Canada, Sweden, and Australia (Table 1). 


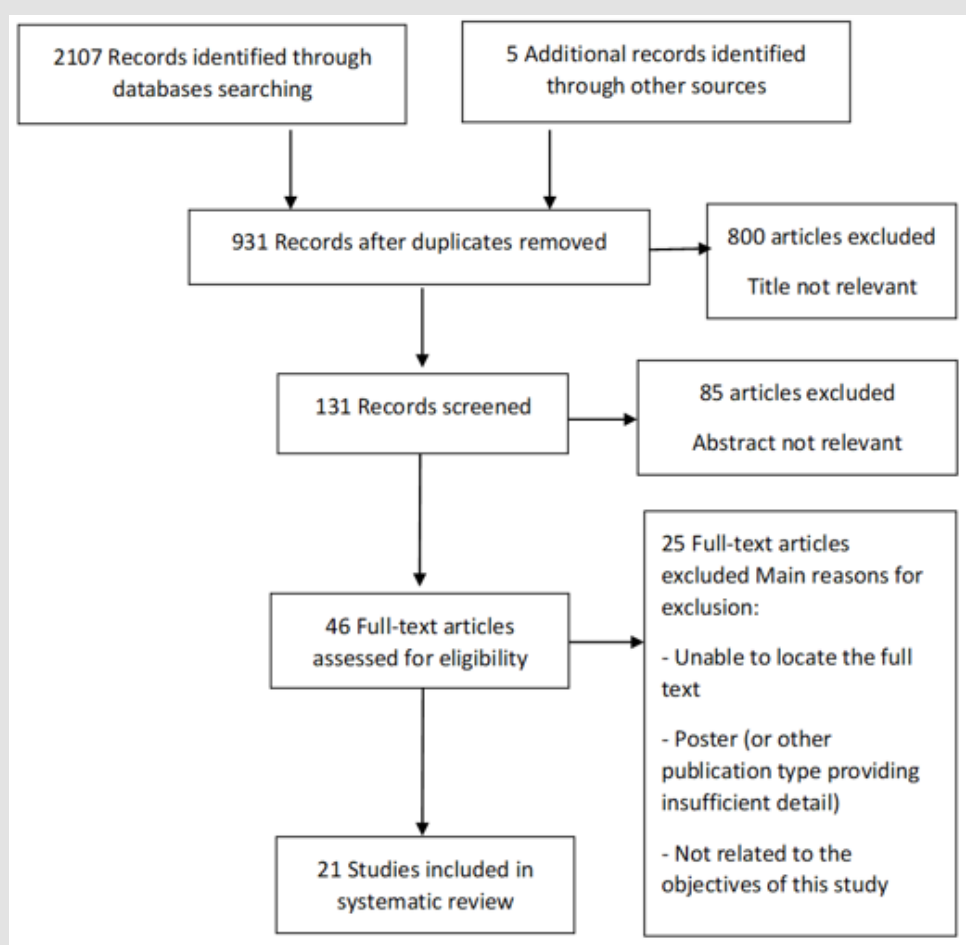

Figure 1: Search strategy flow diagram.

Table 1: Nursing management information systems' features used in different countries.

\begin{tabular}{|c|c|c|c|c|}
\hline Countries & Systems & Services & Components & Data sources \\
\hline \multirow[t]{2}{*}{ Finland } & $\begin{array}{c}\text { Nursing Management } \\
\text { Information System with Data } \\
\text { Warehouse Approach [26] }\end{array}$ & $\begin{array}{l}\text { - Managing human resources · } \\
\text { •Managing financial resources · } \\
\text { •Assessing nursing performance } \\
\text { and clinical procedures }\end{array}$ & - & $\begin{array}{l}\text { - Outpatient and Inpatient } \\
\text { Administrative System. } \\
\text { •Operating Room IT-system } \\
\text { •Personnel rostering system }\end{array}$ \\
\hline & $\begin{array}{l}\text { 1. Electronic Nursing Managem- } \\
\text { ent System to Facilitate Interdis- } \\
\text { ciplinary Communication and } \\
\text { Improve Patient Outcomes } \\
\text { in Psychiatric Hospitals } \\
\text { (PSYCHOM) [32] }\end{array}$ & $\begin{array}{l}\text { - Managing the condition and care } \\
\text { needs of patients. } \\
\text {-Management, scheduling and } \\
\text { employing human resources with } \\
\text { regard to patient care needs }\end{array}$ & $\begin{array}{l}\text { - Clinical pathway and } \\
\text { variance analysis system } \\
\text { - Nursing manager and } \\
\text { staffs daily recording system } \\
\text { - Nursing care planning } \\
\text { system } \\
\text { Nursing management } \\
\text { support system }\end{array}$ & - \\
\hline Japan & $\begin{array}{l}2 . \quad \text { Nursing Administration } \\
\text { Analysis System PSYCHOMS } \\
{[16]}\end{array}$ & $\begin{array}{l}\text { - Managing human resources } \\
\text { (Nursing Management and } \\
\text { Personnel Distribution) - Quality } \\
\text { management of nursing services } \\
\text { - Providing necessary data to } \\
\text { confirm the compliance of the } \\
\text { treatment fees and working } \\
\text { conditions with the Labor } \\
\text { Standards Law }\end{array}$ & $\begin{array}{l}\text {-Clinical pathway analysis } \\
\text { system } \\
\text {-Patient status and } \\
\text { dynamics analysis •System } \\
\text { Patient status and dynamics } \\
\text { analysis system } \\
\text {-Staff information Analysis } \\
\text { System }\end{array}$ & $\begin{array}{l}\text { - Clinical Pathway System } \\
\text { •Electronic Health Record } \\
\text {-Ward Log System Database } \\
\text { - Nursing Care Plan System } \\
\text { - Nursing Staff Administration } \\
\text { - Work Schedule System }\end{array}$ \\
\hline China & $\begin{array}{l}\text { Decision Support System of } \\
\text { Nursing Human } \\
\text { Allocation [33] }\end{array}$ & $\begin{array}{l}\text { - Managing workload } \\
\text {-Managing human resources } \\
\text { allocation according to the } \\
\text { severity of patients' needs }\end{array}$ & - & $\begin{array}{l}\text { - Hospital Information System } \\
\text { - Doctor Order system } \\
\text { - Nursing activities system } \\
\text { - Patient acuity of ward system }\end{array}$ \\
\hline
\end{tabular}




\begin{tabular}{|c|c|c|c|c|}
\hline Norway & $\begin{array}{c}\text { Nursing managers decision } \\
\text { support system CLASSICA } \\
{[34,35]}\end{array}$ & $\begin{array}{l}\text { - Planning, managing and } \\
\text { allocating financial resources } \\
\text { - Planning nursing and employing } \\
\text { human resources } \\
\text { - Balancing the budget } \\
\text { - Quality assurance of nursing } \\
\text { care } \\
\text { - Productivity management } \\
\text { - Cost control and monitoring } \\
\text { - Performance Management with } \\
\text { budgeting }\end{array}$ & $\begin{array}{l}\text { - Data entry } \\
\text { - Reports } \\
\text { - Management and } \\
\text { simulation (WHAT-IF } \\
\text { conditional prediction and } \\
\text { analysis options) }\end{array}$ & - \\
\hline $\begin{array}{l}\text { United states } \\
\text { of America } \\
\text { (Atlanta) }\end{array}$ & $\begin{array}{l}\text { Computerized staffing and } \\
\text { scheduling system [36] }\end{array}$ & $\begin{array}{l}\text { - Planning and tracking staffing } \\
\text { assignments } \\
\text { - Budget management } \\
\text { - Managing patient care through } \\
\text { the proper distribution of human } \\
\text { resources }\end{array}$ & & - \\
\hline $\begin{array}{l}\text { Nordic } \\
\text { Countries }\end{array}$ & $\begin{array}{l}\text { The RAFAELA system: a } \\
\text { workforce planning tool for } \\
\text { nurse staffing and human } \\
\text { resource management [36-43] }\end{array}$ & $\begin{array}{l}\text { - Operational and strategic } \\
\text { management of nursing resources } \\
\text { - Effective allocation of nursing } \\
\text { resources in line with the patient's } \\
\text { actual clinical needs } \\
\text { - Improving nursing care } \\
\text { and, consequently, improving } \\
\text { outcomes } \\
\text { - Measuring the productivity of } \\
\text { nursing staff } \\
\text { - Improving patient-centered care } \\
\text { - Budget planning and calculation } \\
\text { of costs (calculation of costs per } \\
\text { day or per period of care) } \\
\text { - Providing information to related } \\
\text { organizations in order to calculate } \\
\text { costs and make adjustments }\end{array}$ & $\begin{array}{l}\text {-OLUE patients classification } \\
\text { instrument } \\
\text { - Calculation of nursing } \\
\text { resources } \\
\text { - Professional Assessment } \\
\text { of Optimal Nursing Care } \\
\text { Intensity Level (PAONCIL) }\end{array}$ & - \\
\hline Italy & $\begin{array}{l}\text { Nursing care score system } \\
\text { (NCS) [44] }\end{array}$ & $\begin{array}{l}\text { - Assessing patient care needs } \\
\text { - Measuring workload } \\
\text { - Optimal human resources } \\
\text { allocation (nurse patient ratio) } \\
\text { - Reducing the chance of errors, } \\
\text { improving the quality of care and } \\
\text { increasing patient safety }\end{array}$ & - & - \\
\hline $\begin{array}{l}\text { Canada } \\
\text { (Ontario) }\end{array}$ & Nursing dashboard [45] & $\begin{array}{l}\text { - Nurse staffing } \\
\text { - Determining the health status or } \\
\text { patient care needs } \\
\text { - Coordinating the characteristics } \\
\text { and needs of patients and } \\
\text { determining the amount of } \\
\text { nursing care and skills required } \\
\text { - Providing indicators for } \\
\text { assessing the level of nursing staff } \\
\text { to provide high quality care } \\
\text { - Monitoring }\end{array}$ & - & $\begin{array}{l}\text { Nursing information, } \\
\text { information/patient databases } \\
\text { within the Decision support } \\
\text { Department at Hamilton } \\
\text { Health Sciences (HHS) }\end{array}$ \\
\hline
\end{tabular}




\begin{tabular}{|c|c|c|c|c|}
\hline Sweden & $\begin{array}{l}\text { Patient Classification } \\
\text { System[46] }\end{array}$ & $\begin{array}{l}\text { - Effective planning of nursing } \\
\text { resources } \\
\text { - Determining the care needs of } \\
\text { patients } \\
\text { - Determining various sources } \\
\text { used } \\
\text { - Budget planning in nursing } \\
\text { services } \\
\text {-Service quality evaluation } \\
\text {-Workload measurement } \\
\text { - Nurse staffing }\end{array}$ & $\begin{array}{l}\text { - Zebra } \\
\text { - Patient classification tool } \\
\text { - Study activities } \\
\text { - Investigation of Human } \\
\text { Resources (Reality and } \\
\text { Needed) } \\
\text { - Records deficiencies in } \\
\text { the quality of nursing care } \\
\text { in cases where adequate } \\
\text { human resources are not } \\
\text { employed. } \\
\text { - Beakta } \\
\text { - Workload measurement / } \\
\text { patient evaluation } \\
\text { - Study activities } \\
\text { - Employing human } \\
\text { resources } \\
\text { - Rush Medicus } \\
\text { - Includes a list of indicators } \\
\text { and their values }\end{array}$ & - \\
\hline $\begin{array}{l}\text { United states of } \\
\text { America }\end{array}$ & $\begin{array}{c}\text { Patient Classification System } \\
\text { MEDICUS [47] }\end{array}$ & $\begin{array}{l}\text {-Patientsallocation } \\
\text { - Employing human resources } \\
\text { - Budget management } \\
\text { - Guidance } \\
\text { - Correct decisions and judgments } \\
\text { - Analysis of trends } \\
\text { - Reviewing workload and } \\
\text { productivity } \\
\text { - Performance tracking } \\
\text { - Clarifying } \\
\text { - Comparing } \\
\text { - Reporting } \\
\text { - Creating a database } \\
\text { - Calculation of costs } \\
\text { - Education and Research }\end{array}$ & - & \\
\hline \multirow[t]{2}{*}{ Australia } & $\begin{array}{l}\text { 1.Patient Assessment and } \\
\text { Information System (PAIS) [48] }\end{array}$ & $\begin{array}{l}\text { - Patient classification } \\
\text { - Workload measurement } \\
\text { - Nurse Staffing }\end{array}$ & & \\
\hline & $\begin{array}{l}\text { 2. Nurse-patient ratio system } \\
\text { (NPR) [49] }\end{array}$ & $\begin{array}{l}\text { - Workload measurement } \\
\text { - Coordinating nurse patient ratio }\end{array}$ & - & \\
\hline
\end{tabular}

\section{Discussion}

The purpose of this systematic review was to examine the features of nursing management information systems used in different countries. We attempted to show not only the services of various nursing management information systems, but also their data sources and components from the 21 articles that met the inclusion criteria in our literature search. Results suggested that, although a nursing management information system is expected to help nursing managers in all dimensions in order for them to play their logistic roles in line with organizational goals, the purpose of nursing management information systems in the studied countries was often planning and managing human resources, measuring the nursing workload, determining the correct nurse-to-patient ratio, managing shifts, and controlling the costs. A similar study entitled "Information systems in hospitals: a review article from a nursing management perspective" by Murtola et al. revealed similar results. In this study, nursing managers accessed four types of available information systems for

a) Planning and evaluating performance,

b) Measuring the workload and allocating resources,

c) Managing shifts, and

d) Communicating [17].

Therefore, the problem with these systems was that they were single-purpose and non-flexible concerning different needs. Murtola further stated that none of the existing systems provided 
support for nursing managers at any management level. In certain nursing management information systems implemented in different countries, mention was made of the ability to provide further services. For instance, in MEDICUS patient classification system, in addition to allocating patients, staffing, managing the budget, and calculating the costs, other issues such as guidance, properly decision-making and judgement, analysis of trends, workload and productivity review, performance tracking, clarification, comparison, reporting, database creation, education and research were also mentioned. Overall, the information systems which have been designed considering classification systems could meet users with further functionality than systems developed ignoring these systems. They classify patients according to the severity of the need for nursing care and services.

These classifications provide patients with nursing care, not merely based on the medical diagnosis of patients or the number of nursing staff. On the other hand, the care needs of patients in these systems are determined based on several nursing components, such as planning and coordinating care, respiration, blood circulation, symptoms, nutrition, medication, personal hygiene, excretion, activity/movement, teaching, guidance, and follow-up [42]. In this way, these systems are able to improve patient-focused care by identifying the care needs of each individual. Therefore, assigning nursing staff to patients, and the type and level of the skills of the personnel are taken into account according to patients needs. Improving the quality and management of risks was another outcome of this classification and this group of nursing management information systems. Furthermore, the review of the literature suggested that most countries used PCS systems to support nursing managers in performing their tasks. Classification systems were implemented in different countries under different titles. Patient classification systems were first used in the United States, followed by countries such as Australia. In Australia, this system was known as the Patient Assessment and Information System (PAIS).

The PAIS utilized dependency indicators to classify patients into six groups. Based on the amount of time required for each indicator and the sum, the required care period was specified for each patient. The higher the number of indicators for each patient, the more the workload and the higher the number of nursing resources. Another system implemented in Australia was the Nurse-to-Patient Ratios System, which was based on workload measurement. This system ensured coordination between the number of patients and the number of nurses. Implementation of Nurse-to-Patient Ratios System has been mandatory in Australian public departments since 2000. Australia implemented this system following the mandatory enforcement of such systems in the United States of America, including California and 16 other states $[48,49]$. In the United States, Medicus PCS was one of the largest PCSs used in more than 400 hospitals nationwide [49]. In fact, it can be stated that systems entitled nursing managers' information systems mentioned in this review were those based on patient classification systems or workload measurement. They also included systems made by integrating nursing resource information with hospital resource measurement and providing managerial information to support planning and budgeting. Workload measurement systems used different methodologies to measure the workload, some of which were task-based and focused on nursing tasks and standard times. Others used patients' care needs to classify patients according to their need for care, and then assigned the number of hours required to provide this type of patient care. The nursing dashboard is also used in Canada to support nursing management decision-making, employing nursing staff, determining the health condition or patient care needs, coordinating the characteristics and needs of patients, and specifying the amount of nursing care and required skills. The system also provides indicators for assessing the appropriate nursing staffing level to provide quality care and service monitoring. In the nursing management information systems in other countries, no significant services were mentioned other than human resource planning and management, nursing workload measurement and control, or budget or cost management.

The literature review further demonstrated that limited studies have investigated data sources, and this issue has been addressed only by the studies on the "nursing management information system with a data warehouse approach" in Finland, PSYCHOM, the Nursing Management Analysis System in Japan, and the decision support system in allocating nursing resources in China. The data sources mentioned in these systems revealed that these systems do not have a focused or consistent database for obtaining the information required for nursing management purposes, and nursing managers had to receive data from other existing information systems. Another study by Murtola entitled "Governance of managerial Information needed by nursing managers in hospitals - a literature review" pointed out to the same issue, claiming that nursing managers used different information systems to meet their information needs, and the lack of integrity of these systems was a serious problem [19]. Reviewing the components of the examined information systems showed different components for each system. For instance, the electronic nursing management system had four main components for communication and improvement of the outcomes of patients with PSYCHOM.

These four components were:

1) Clinical pathway and variance analysis system,

2) Nursing manager's and employees' daily recording system,

3) Nursing care planning system, and

4) The nursing management support system.

This system contained the necessary data for all people in the care team and improved their communication. Serious patient problems were identified and communicated to the oncoming shift in the nursing manager's and employees' daily recording system and nursing management support system with PSYCHOMS. This system made nursing data available at any point in the 
hospital and permitted nursing managers to track the number of hospital patients and the type of care they needed. The Nursing Management Analysis System also had four components which obtained their data from various databases. The component of the clinical pathway received data from the clinical pathway system database; the component of status analysis and patient dynamics obtained data from the electronic health record database and ward log system database; the component of the analysis of ward features received data from the nursing care plan system database, nursing staff administration database, electronic health records database, and ward log system database; and the component of personnel information analysis received data from the work schedule system database. The acquired information was then provided to the nursing manager. Other systems with their components were discussed in the findings. Regarding the services expected from the applied system, these components receive inputs, process them, and generate the output data.

\section{Conclusion}

In order to effectively support nursing managers, an information system must provide the essential information to support decisionmaking for patient care management, improve patient outcome, effectively manage resources, allocate resources, plan the activities, balance the budget, correct budget deviations, and provide timely evaluation and report. These systems should be able to show the link between costs and services in an easily applicable and interpretable manner. They should also include analysis and forecast options for examining the current and future trends, facilitating long-term planning, and reducing costs. One of the final criteria in assessing an effective management information system is decreasing and controlling the costs. Therefore, financial results should be easily visible and monitored. The ease of use and nursing manager satisfaction are also significant. Likewise, in addition to supporting nursing managers in tactical planning and decisionmaking, nursing management information systems must be able to aid nursing managers in planning, strategic decision-making, and tasks that do not have only an administrative perspective. Results of the present review revealed that these systems focus on the management dimension of nursing management tasks. On the other hand, nursing managers need an integrated database to receive the required data. The minimum requirement is a consistency between the information systems from which the nursing manager receives the required data.

\section{Implications for Nursing Managers}

Nowadays, there is an increase in the various responsibilities of nursing managers and their need for timely support. An increase is also seen in the use of nursing management information systems by health care organizations. Consequently, in order to maximize the benefits of implementing a consistent nursing management information system, nursing managers must become more familiar with the features of such systems. In most cases, nursing management information systems are designed while the needs of nursing managers have not been precisely and completely taken into consideration. The optimal way to solve this problem is to inform nursing managers of the features of a proper nursing management information system and to engage them in designing and implementing the phases. Findings of the present review may assist nursing managers in defining information needs and requirements for the design and implementation of a nursing management information system.

\section{References}

1. Behdioğlu S, Acar E, Burhan HA (2019) Evaluating service quality by fuzzy SERVQUAL: A case study in a physiotherapy and rehabilitation hospital. Total Qual Manag Bus Excell 30(3-4): 301-319.

2. Mohseni M, Raeisi A, Azami Aghdash S, Moosavi A, Mousavi SM (2017) Hospital Services Quality from Patients' viewpoint in Iran: A Systematic Review and Meta-Analysis. Evid based Health Policy, Manag and Econ 1(4): 261-269.

3. Moosavi A, Mohseni M, Ziaiifar H, Azami Aghdash S, Manshadi MG, et al. (2017) The Quality of Educational Services from Students' Viewpoint in Iran: A Systematic Review and Meta-analysis. Iran J Public Health 46(4): 447-455.

4. (2018) Agency for Healthcare Research and Quality. Understanding Quality Measurement.

5. Gupta KS, Rokade V (2016) Importance of Quality in Health Care Sector: A Review. J Health Manag 18(1): 84-94.

6. Crowell DM (2015) Complexity Leadership: Nursing's Role in HealthCare Delivery: FA Davis; $2^{\text {nd }}$ (Edi.).

7. O Dwyer C (2014) The Introduction of Clinical Microsystems into an Emergency Department. [MSc Thesis]. Dublin: Royal College of Surgeons in Ireland.

8. Bender M, Connelly CD, Glaser D, Brown C (2012) Clinical nurse leader impact on microsystem care quality. Nurs Res 61(5): 326-332.

9. Poniatowski L, Stanley S, Youngberg B (2005) Using information to empower nurse managers to become champions for patient safety. Nurs Adm Q 29(1): 72-77.

10. Clifford J (2015) Evaluation of a Reflective Team Coaching Model as a Leadership Strategy for Nurse Managers to Cultivate Front Line Quality and Safety Improvement Capability: MGH Institute of Health Professions.

11. Mororó DDdS, Enders BC, Lira ALBdC, Silva CMBd, Menezes RMPd (2017) Concept analysis of nursing care management in the hospital context. Acta Paulista de Enfermagem 30(3): 323-332.

12. American Nurses Association (2016) Nursing Administration: Scope and Standards of Practice, Second Edition. American Nurses Association, Inc.

13. Australian Colledge of Nursing(ACN) (2015) Nurse Leadership A White Paper by ACN.

14. Armstrong SJ, Rispel LC, Penn Kekana L (2015) The activities of hospital nursing unit managers and quality of patient care in South African hospitals: a paradox? Glob Health Action 8: 26243.

15. Peñarrieta de Córdova MI, Castañeda Hidalgo H, Acevedo Porras G, Rangel Torres S, González Salinas F, et al. (2014) Role and working conditions of hospital nurse managers: A binational study from Peru and Mexico. J Hosp Adm 3(3): 91.

16. Miyagawa M, Tanioka T, Yasuhara Y, Kazuyuki Matsumoto, Hirokazu Ito, et al. (2014) Methodology for Developing a Nursing Administration Analysis System. Intell Inf Manag 6(3): 118.

17. Murtola LM, Lundgrén Laine H, Salanterä S (2013) Information systems in hospitals: a review article from a nursing management perspective. Int J Netw Virtu Organ 13(1): 81-100.

18. Murphy LS, Scott ES, Warshawsky NE (2014) Nursing administration research: an evolving science. J Nurs Adm 44(12): 622-624. 
19. Laura Maria Murtola, Heljä Lundgrén Laine, Sanna Salanterä (2012) Governance of Managerial Information Needed by Nurse Managers in Hospitals - A Literature Review. International Conference on Well-Being in the Information Society 313: 104-118.

20. Moghaddasi H (2017) The Influence of Informatics on Nursing Care and Professional Development. JOJ NHC 4(3): 555639.

21. Choi M, Yang YL, Lee SM (2014) Effectiveness of nursing management information systems: a systematic review. J Healthc Inform Res 20(4): 249-257.

22. Hannah KJ, Hussey P, Kennedy MA, Ball MJ (2015) Introduction to Nursing Informatics. $4^{\text {th }}$ (edi.). Verlag London: Springer.

23. Saba VK, Pocklington DB, Miller KP (2012) Nursing and computers: An anthology, 1987-1996. New York: Springer Science \& Business Media.

24. van den Oetelaar W, Van Stel H, Van Rhenen W, Stellato R, Grolman W (2016) Balancing nurses' workload in hospital wards: study protocol of developing a method to manage workload. BMJ open 6(11): e012148.

25. Swiger PA, Vance DE, Patrician PA (2016) Nursing workload in the acute-care setting: A concept analysis of nursing workload. Nurs outlook 64(3): 244-254.

26. Junttila K1, Meretoja R, Seppälä A, Tolppanen EM, Ala Nikkola T, et al. (2007) Data warehouse approach to nursing management. J Nurs Manag 15(2): 155-161.

27. Kontio E, Airola A, Pahikkala T, Lundgren Laine H, Junttila K, et al. (2014) Predicting patient acuity from electronic patient records. J Biomed Inform 51: 35-40.

28. Wilson J (1989) Nurse management information system. Nursing Standard 3(34): 24-25

29. Shojaei S, Farzianpour F, Arab M, Foroushani AR (2016) An Investigation on the Status of Implementation of Communications and Information Management System (MCI) in Khorasan Razavi Hospitals. Glob J Health Sci 8(5): 110-119.

30. Asar S, Jalalpour S, Ayoubi F, Rahmani M, Rezaeian M (2016) PRISMA Preferred Reporting Items for Systematic Reviews and Meta-Analyses. J Raf Uni Med Sci 15(1): 68-80.

31. Moher D, Shamseer L, Clarke M, Ghersi D, Liberati A, et al. (2015) Preferred reporting items for systematic review and meta-analysis protocols (PRISMA-P) 2015 statement. Syst Rev 4: 1.

32. Tanioka T, Osaka K, Chiba S, Parker C, Yasuhara Y, et al. (2011) PSYCHOMS ${ }^{\circ}$ An electronic nursing management system to facilitate interdisciplinary communication and improve patient outcomes in psychiatric hospitals. $20117^{\text {th }}$ International Conference on Natural Language Processing and Knowledge Engineering. IEEE Pp. 447-453.

33. Chen H, Zhao S, Feng L (2016) Decision Support System of Nursing Human on Hospital Information System. Stud Health Technol Inform 225: 558-561.

34. Ruland CM (2001) Developing a decision support system to meet nurse managers' information needs for effective resource management. Comput Nurs 19(5): 187-193.

\section{ISSN: 2574-1241}

DOI: 10.26717/BJSTR.2019.21.003582

Hamid Moghaddasi. Biomed J Sci \& Tech Res

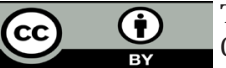

This work is licensed under Creative

Commons Attribution 4.0 License

Submission Link: https://biomedres.us/submit-manuscript.php
35. Ruland CM, Ravn IH (2003) Usefulness and effects on costs and staff management of a nursing resource management information system. J Nurs Manag 11(3): 208-215.

36. Vautier A, Connor J, Fragala P, Hart M, Brown K, et al. (2003) The Emory experience. Nurs Adm Q 27(1): 18-28.

37. Andersen MH, Lønning K, Fagerström L (2014) Testing reliability and validity of the Oulu patient classification instrument-the first step in evaluating the RAFAELA system in Norway. Open J Nurs 4(4): 303.

38. Aschan H, Junttila K, Fagerstrôm L, Kanerva A, Rauhala A (2009) RAFAELA Patient Classification System as a tool for management. Stud Health Technol Inform 146: 478-482.

39. Fagerström L (2009) Evidence-based human resource management: a study of nurse leaders' resource allocation. J Nurs Manag 17(4): 415425 .

40. Fagerström L, Lønning K, Andersen MH (2014) The RAFAELA system: a workforce planning tool for nurse staffing and human resource management. Nurs Manag (Harrow) 21(2): 30-36.

41. Hustad NB, Hellesø R, Andersen MH (2015) A qualitative study of manager experiences using the RAFAELA system. Open J Nurs 5: 12241232.

42. Lillehol BM, Lønning K, Andersen MH (2018) Exploring nurse managers' perception of using the RAFAELA system as a management tool in a Norwegian hospital setting. Nurs Open 5(1): 77-83.

43. Rainio AK, Ohinmaa AE (2005) Assessment of nursing management and utilization of nursing resources with the RAFAELA patient classification system-case study from the general wards of one central hospital. J Clin Nurs 14(6): 674-684.

44. Giammona S, Arena G, Calò M, Maria Angela Barone, Davide Scelsa, et al. (2016) Nursing workload and staff allocation in an Italian hospital: a quality improvement initiative based on nursing care score. Cent Eur J Nurs Midw 7(2): 420-427.

45. Fram N, Morgan B (2012) Ontario: linking nursing outcomes, workload and staffing decisions in the workplace: the dashboard project. Nurs Leadersh 25(Sp).

46. Perroca MG, EK AC (2007) Utilization of patient classification systems in Swedish hospitals and the degree of satisfaction among nursing staff. J Nurs Manag 15(5): 472-480.

47. Botter ML (2000) The use of information generated by a patient classification system. J Nurs Adm 30(11): 544-551.

48. Duffield C, Roche M, Merrick ET (2006) Methods of measuring nursing workload in Australia. Collegian 13(1): 16-22.

49. Heslop L, Plummer V (2012) Nurse staff allocation by nurse patient ratio vs. a computerized nurse dependency management system: a comparative cost analysis of Australian and New Zealand hospitals. Nurs Econ 30(6): 347-355.

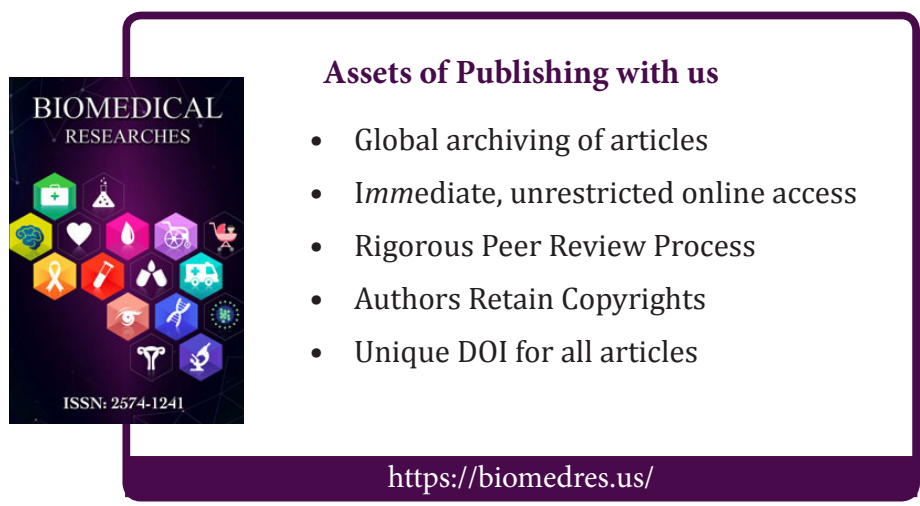

Copyright@ Hamid Moghaddasi | Biomed J Sci \& Tech Res | BJSTR. MS.ID.003582. 